Pedagogy

Mashbic, 1990 - Mashbic, Ja.G. (1990). Tendencii razvitija geograficheskoj mysli [Trends in the Development of Geographical Thought]. Proceedings of the Academy of Sciences of the USSR. Series: Geography, 4, 1727.

Mereste, 1984 - Mereste, U.I., Nimmik, S. Ja. (1984). Sovremennaja geografija: voprosy teorii [Modern Geography: Theoretical Problems]. Moscow: Mys1, 296.

Mukitanov, 1985 - Mukitanov, N.K. (1985). Ot Strabona do nashih dnej [From Strabo to the Today]. Moscow: Mysl, 234.

Pokshishevskij, 1974 - Pokshishevskij, V.V. (1974). O samom glavnom v jekonomicheskoj geografi [On the Most Important in Economic Geography]. Problems of Geography, 95, 25-42.

Pokshishevskij, 1979 - Preobrazhenskij, V.S. (1979). Fenomen geografii (razdum'ja geografa) [Geographical Phenomenon (Thoughts of Geographer)]. Proceedings of the Academy of Sciences of the USSR. Series: Geography, 4, 20-27.

Saushkin, 1980 - Saushkin, Ju.G. (1980). Geograficheskaja nauka v proshlom, nastojashhem, budushhem: Posobije dlja uchititelej [Geographical Sciences in the Past, Present, Future: Textbook for Teacher]. Moscow: Prosveshcheniie, 269.

Perspektivy geografii, 1976 - Perspektivy geografii [Prospects of Geography]. (1976). One Hundred Collections «Problems of Geography». Moscow: Mysl, 100, 254.

Topchijev, 2001 - Topchijev, O.H. (2001). Osnovy suspil'noji heohrafiji: Navch. Posibnyk [Basis of Social Geography: Manual]. Odesa: Astroprynt, 560.

Topchijev, 2006 - Topchijev, O.H. (2006). Konceptual'no-ponjattjevyjj aparat i predmetna oblast' heohrafiji [Conceptual Apparatus and Subject Area in Geography]. Theoretical and Methodological Problems of Social Geography: Coll. Scien. Works in Honour of Honoured Professor of Lviv Ivan Franko National University Oleh Shablii. Lviv: Pub. Center LNU named by Ivan Franko, 77-84.

Shablij, 2012 - Shablij, O.I. (2012). Osnovy suspil'noji heohrafiji: pidruchnyk dlja studentiv vyshchykh navchalnykh zakladiv [Basis of Social Geography: Textbook for Students of Higher Education Institutions]. Lviv: LNU named by Ivan Franko, 296.

Barans 'kij, 1965 - Barans'kij, N.N. ed. (1965). Jekonomicheskaja geografija v SSSR: istorija i sovremennoe razvitie [Economic Geography in the USSR: History and Modern Development]. Moscow: Prosveshcheniie, 653.

УДК 378.011.3-051:57

Лариса Шаповал,

кандидат педагогічних наук, дочент кафедри біології та методики навчання ДВНЗ «Переяслав-

Хмельницький державний педагогічний університет імені Григорія Сковороди».
DOI 10.31470/2308-5126-2019-2-44-162-168

Larysa Shapoval,

PhD. in Pedagogy, Associate Professor

of the Department of Biology and

Methods of Teaching

«Pereiaslav-Khmelnytskyi Hryhorii

Skovoroda State Pedagogical

University».

E-mail: shapovallarisa@ukr.net

ORCID 0000-0003-1250-0806

\title{
ФОРМУВАННЯ ПОНЯТЬ ЯК ВАЖЛИВИЙ АСПЕКТ МЕТОДИЧНОЇ ПІДГОТОВКИ МАЙБУТНЬОГО ВЧИТЕЛЯ БІОЛОГІЇ У КОНТЕКСТІ КОМПЕТЕНТНІСНОГО ПІДХОДУ ДО НАВЧАННЯ
}

У статі проаналізовано теоретичні та прикладні аспекти формування понять в учнів 7-х класів загальноосвітніх закладів середньої освіти у процесі вивчення біології. Теоретично обтрунтовано важливість врахування компетентісного підходу до методичної підготовки майбутнього вчителя біології. Розкрито основні педагогічні умови, реалізачія яких у процесі діяльності майбутнього вчителя біологї сприяє успішному засвоєнню учнями біологічних термінів та понять. Визначено критерії оцінювання рівня сформованості понять. Розкрито засоби формування понять.

Вказано на важливість володіння вчителем змісту поняття, щчо формується, розуміння його місия і ролі в системі понять даної галузі знань; розуміння вчителем значення формування даного поняття в учнів (навчальне, виховне, світоглядне); знання основних вимог, яким має задовольняти засвоєне учнями поняття 
(згідно програми з навчальної дисципліни); розуміння основних етапів формування поняття; уміння здійснювати розширення змісту та обсягу поняття; володіння мнемічними методами, що забезпечують відтворення учнями змісту цих понять; знання типових помилок в засвоєнні поняття, причин їх виникнення та шляхів попередження цих помилок при формуванні даного поняття.

Ключові слова: компетентісний підхід до навчання, методика викладання біології, біологічні поняття та терміни, формування та розвиток понять і термінів, методична підготовка майбутніх вчителів біологї, учні 7-х класів.

The theoretical and applied aspects on formation of notions in the studying Biology by the seven form pupils are analyzed in the paper. Specific terms and notions of the course are separated out for the improvement of the methodological approaches in the process their formation.

The author's approach to solving the issues of the methods on formation specific biological terms and notions of selected topics of the course is shown. The paper describes the works of Ukrainian and foreign scientists in the development of general theoretical principles in the formation of biological notions in general educational institutions.

The paper points out the need to pay more attention to describe applied aspects on formation of biological notions, which are the basis of scientific knowledge. Particular attention is paid to define the notion as an image that fixes the general and essential characteristics and properties of objects and phenomena and the relationship between them. The author indicates that being a form of reflection of reality the notion reflects the essential characteristics of objects, processes or phenomena and the relationship between them, and the process of formation of the notion involves identifying these characteristics and their consciousness.

It is noted that the finding of essential characteristics of the notion in their relationship can and have to occur in the process of analysis of its definition It is on the detection of these links and have to be directed the pupil's activities in the studying of new biological notions and terms. The paper describes a sequence of analytic actions of pupils, namely, analyzing the definition of a notion, they detect a keyword or word-combination, and then, through the system of consistent questions of the teacher, reveal the connections and dependencies between the essential characteristics and properties that make up the essence of the definition of a notion.

After analytical activities on separating substantial, the author of the study points out the need to organize work for the definition of a concept. As a result of this in pupils develop the ability to synthesize, since it gives the opportunity to combine parts of the object, dissected in the process of analysis, establish their connections and get to know the object as a whole.

Keywords: Biology Teaching Methodology, formation and development of notions and terms, analysis, synthesis, essential features, textbooks of Biology, pupils of the seventh forms, biological notions and terms.

Постановка проблеми. Реалізація основних положень компетентнісного підходу - один із перспективних шляхів реформування освіти в Україні. Він забезпечує поступову переорієнтацію системи освіти, що грунтувалася на дидактичній тріаді «знання-уміння-навички» на освіту, спрямовану на формування компетентного члена суспільства, який здатен застосовувати свої знання в умовах, що змінюються, «на формування в майбутнього фахівця готовності ефективно використовувати потенційні можливості (знання, уміння, навички, цінності, психологічні особливості) та зовнішні ресурси (інформаційні, людські, матеріальні) для досягнення поставленої мети [Кузьмінський, 2012: с. 4].

Компетентність характеризує ступінь «включення» до активної діяльності, здатність ефективно діяти в конкретних ситуаціях, мобілізуючи при цьому знання, уміння, досвід, цінності та ін. [Колективна монографія, 2004: с. 6].

Ключовою фігурою реформ у освітній галузі $\epsilon$ вчитель. У зв'язку з цим виникає необхідність суттєвого переосмислення професійної підготовки майбутніх учителів, спрямованої на формування у них здатності і до виконання завдань $\mathrm{i}$ обов'язків діяльності. Серед досліджень, присвячених питанням формування професійних якостей чи компетентностей учителя, слід відзначити роботи В. Андрущенка， Н. Бібік， О. Біди， Л. Вовк， І. Ісаєва， Н. Кузьміної， В. Лозової, 
Д. Ніколенка, О. Овчарук, О. Пометун, О. Савченко, С. Чистякової, М. Шкіля, А. Хуторського та ін.

Відповідно до нових вимог реформування потребує процес підготовки сучасного вчителя біології, у тому числі й 3 точки зору формування у нього відповідних професійних компетентностей. Особливості методичної підготовки майбутніх вчителів біології досліджували В. Вербицький, Н. Грицай, Г. Жирська, Н. Міщук, І. Мороз, А. Степанюк, О. Цуруль та ін.

Аналіз останніх досліджень і публікацій. Науково-теоретичне опрацювання публікацій вітчизняних і зарубіжних учених засвідчує активну розробку таких аспектів проблеми дослідження: обгрунтування загальнотеоретичних засад формування біологічних понять у загальноосвітніх навчальних закладах (М. Верзілін, І. Звєрєв, О. Казакова, В. Корсунська, Н. Риков та ін.); визначальні фактори формування понять в учнів (В. Давидов, В. Паламарчук, Т. Тализіна, Є. Кабанова-Меллєр, А. Маркова та ін.); різноманітні аспекти формування термінів та понять у процесі роботи зі шкільним підручником (В. Беспалько, А. Гірняк та ін.); формування біологічних термінів та понять в курсі окремих навчальних дисциплін (Н. Лакоза, Є. Неведомська, О. Цуруль та ін.).

Попри значну кількість праць, присвячених професійній підготовці вчителя біології, зважаючи на багатоаспектність розглядуваної проблеми, низка питань залишаються не вирішеними. Зокрема потребує подальшого дослідження питання формування в майбутніх учителів уміння організовувати роботу учнів 3 біологічними термінами та поняттями, визначення педагогічних умов, реалізація яких у процесі навчання сприяє їх успішному засвоєнню.

Mema cmammi полягає у розкритті основних педагогічних умов, реалізація яких у процесі діяльності майбутнього вчителя біології сприяє успішному засвоєнню учнями біологічних термінів та понять та у визначенні критеріїв оцінювання рівня їх сформованості.

Виклад основного матеріалу. В умовах зростання соціальної ролі школи й учителя підготовка педагогічних кадрів повинна якомога повніше грунтуватися на поєднанні глибокого засвоєння теоретичних основ фахових дисциплін із формуванням практичних умінь застосовувати ці знання у педагогічній практиці. Звідси виникає необхідність удосконалення усієї системи методичної підготовки майбутнього вчителя, важливим компонентом якої $\epsilon$ робота 3 термінами та поняттями [Цуруль , 2004: c. 5]. Нові соціальні умови, процес оновлення освітніх структур, компетентісно-орієнтований підхід до навчання знову звертають увагу вчених і педагогів-практиків на цю проблему.

Тому очевидною є необхідність підвищення вимог до якості підготовки майбутніх учителів, здатних успішно реалізовувати роботу з термінами і поняттями як основу навчальної діяльності.

Проте, як показав досвід проведення педагогічної практики, майбутні вчителі біології відчувають суттєві труднощі під час термінологічної роботи. Це впливає не лише на результати навчальної діяльності учнів, але й створює чималі труднощі в професійному становленні молодого вчителя.

У зв'язку 3 цим висувається питання пошуку ефективних шляхів удосконалення теоретичної та практичної підготовки студентів до реалізації навчальної функції. 
Одним із найважливіших завдань, які покликана вирішувати школа, є забезпечення засвоєння учнями системи знань основ наук. Основні компоненти системи наукових знань - це наукові факти, поняття, закони, теорії, методи досліджень, наукова картина світу [Лейчик, 2009: с. 15].

Центральним ядром цієї системи є наукові поняття. Без засвоєння понять не можливе свідоме засвоєння законів і теорій, формування наукової картини світу, наукового світогляду, а також вирішення різноманітних виховних завдань.

Все це призводить до висновку про важливість проблеми формування наукових понять в учнів закладів середньої освіти.

Щоб свідомо керувати процесом формування понять, треба знати його основні особливості, закономірності, яким він підпорядковується.

Перш, ніж почати формувати те чи інше поняття, майбутні вчителі ДВНЗ «Переяслав-Хмельницький державний педагогічний університет імені Григорія Сковороди» на заняттях з методики викладання біології засвоюють вимоги, яким має задовольняти опанування нового для учнів поняття; вихідну понятійну базу, яка повинна бути в учнів для успішного засвоєння цього поняття; основні етапи розвитку поняття; оптимальні способи його формування тощо.

Проте часто майбутні фахівці дотримуються тієї послідовності та логіки формування понять, яка реалізована в підручнику або в навчальних посібниках. Тому ефективність цього процесу виявляється досить низькою.

У даній статті поставлено завдання розкрити основні педагогічні умови, реалізація яких в процесі навчання сприяє успішному засвоєнню учнями понять. Проведені дослідження і досвід роботи дозволяють виділити наступні умови:

1. Володіння вчителем змісту поняття, що формується, розуміння його місця і ролі в системі понять даної галузі знань.

2. Розуміння вчителем значення формування даного поняття в учнів (навчальне, виховне, світоглядне).

3. Знання основних вимог, яким має задовольняти засвоєне учнями поняття (згідно програми 3 навчальної дисципліни).

4. Розуміння основних етапів формування поняття. Визначення вимог до засвоєння поняття на кожному етапі його формування (які істотні ознаки поняття повинні бути розкриті, в якій мірі повинен бути розкритий обсяг поняття).

5. Уміння здійснювати розширення змісту та обсягу поняття,

6. Чітке усвідомлення понятійної бази, життєвого та чуттєвого досвіду, на які має спиратися процес формування нового поняття.

7. Володіння мнемічними методами, що забезпечують відтворення учнями змісту цих понять.

8. Знання типових помилок в засвоєнні поняття, причини їх виникнення та шляхів попередження цих помилок при формуванні даного поняття.

9. Володіння методами мотивації понятійно-термінологічної роботи учнів (створення проблемної ситуації, показ невідповідності між наявною понятійною базою і необхідністю введення нового поняття).

10. Здатність використовувати оптимальні методи формування нового поняття:

а) засобами теоретичного аналізу нових наукових фактів; 
б) засобами експерименту;

в) засобами розв'язання завдань практичного характеру;

г) засобами створення проблемних ситуацій тощо.

11. Уміння формувати поняття засобами здійснення аналізу його визначення та синтезу (формування визначення на основі необхідних даних). Найбільш поширеним способом визначення понять в природничих науках є визначення через найближчий рід і видову відмінність. 3 цією метою з учнями можна організувати роботу по, виявленню ключового слова чи словосполучення, 3'ясуванню найзагальнішої ознаки чи ознаки, а потім - його особливостей, конкретних відмінних ознак.

12. Уміння здійснювати міжпредметні зв’язки при формуванні нового поняття.

13. Застосування сформованих понять у вирішенні завдань: а) з даної теми; б) розділу (включаючи матеріал попередніх тем); в) всього курсу; г) 3 даного предмету та суміжних дисциплін, наприклад, з фізики та хімії.

14. Знання вчителем основних критеріїв якості засвоєння понять. Це повнота засвоєння змісту поняття (кількість ознак поняття, що підлягають засвоєнню на даному етапі його формування); повнота засвоєння кількості зв'язків даного поняття з іншими поняттями; повнота засвоєння обсягу поняття.

15. Уміння використовувати критерії оцінювання рівня сформованості поняття.

Охарактеризуємо ці рівні.

Перший рівень (1-3 бали) - учень оперує терміном, що позначає поняття, але не може дати вірне його визначення і відмежувати істотні ознаки поняття від другорядних. Відповідь учня фрагментарна, характеризується початковими уявленнями про предмет вивчення.

Другий рівень (4-6 балів) - учень може дати правильне визначення поняття, відмежувати істотні ознаки від несуттєвих, але не може відмежувати дане поняття від суміжних, подібних за будь-якими ознаками понять. Учень відтворює основний навчальний матеріал, виконує завдання за зразком, володіє елементарними вміннями навчальної діяльності.

Третій рівень (7-9 балів) - учень дає вірне визначення поняття, вірно відмежовує істотні ознаки від несуттєвих, але поняття ще не узагальнене, воно обмежене прикладами, на які спирався вчитель при формуванні поняття. Учень самостійно застосовує знання в стандартних ситуаціях. Відповідь учня правильна, логічна, обгрунтована, хоча у ній бракує власних суджень.

Четвертий рівень (10-12 балів) - учень дає вірне визначення поняття, вірно відмежовує істотні ознаки від несуттєвих, відмежовує дане поняття від інших, подібних до нього за будь-якими ознаками; поняття узагальнене і це дозволяє учневі оперувати поняттям у вирішенні широкого кола завдань в рамках даного предмету, а також завдань міжпредметного та дослідницького характеру. Знання учня $\epsilon$ глибокими, системними; він уміє застосовувати їх для виконання творчих завдань, його навчальна діяльність позначена вмінням самостійно оцінювати різноманітні ситуації, явища, факти, виявляти і відстоювати особисту позицію.

Кожний наступний рівень вимог вбирає в себе вимоги до попереднього, а також додає нові. 
Таким чином, у процесі методичної підготовки майбутніх вчителів біології до формування та розвитку біологічних понять вважаємо за необхідне вчити їх організовувати роботу в такі етапи 1) накопичення та розвиток опорних знань (фактів, супідрядних понять) як основних елементів змісту поняття; 2) інтеграція (синтез) елементів змісту і формулювання на цій основі визначення поняття; 3) використання сформованого поняття як цілісного знання шляхом закріплення i подальшого розвитку (поглиблення, розширення, об'єднання з іншими поняттями, або, навпаки, відділення).

Зазначені етапи є загальними для формування всіх біологічних понять, хоча деякі 3 них мають свою специфіку, обумовлену змістовною суттю, місцем включення в навчальний предмет і гносеологічними особливостями.

Що ж до засобів формування понять, то серед них майбутнім вчителям біології вказують на

-наочність;

-вправи, що уточнюють сприйняття;

- точне і образне слово вчителя;

- замальовування по пам'яті;

- вправи на впізнавання і розрізнення;

-логіку викладу матеріалу;

- запитання, що потребують узагальнення;

- вправи на порівняння, класифікацію, встановлення причинно-наслідкових зв'язків, доведення суджень, висновки та узагальнення;

- систему повторення, що пов'язує уже сформовані знання з новими;

- питання, що пов'язують знання із практичним їх застосуванням тощо.

Нерозуміння або навіть поверхневе уявлення майбутніх учителів про сутність основних педагогічних явищ та процесів, що лежать в основі формування термінів та понять суттєво впливає на їх подальшу професійну діяльність. Успіх діяльності педагога в цьому питанні може бути забезпечений, якщо будуть виконані всі перераховані вище педагогічні умови. I чим повніше вони будуть виконані, тим вищого рівня засвоєння понять буде досягнуто.

Одним з найважливіших аспектів процесу формування поняття є визначення його істотних ознак. 3 цією метою майбутніх вчителів біології на практичних заняттях навчаємо методиці розвитку в учнів розумових операцій аналізу, синтезу, порівняння, синтезу, абстрагування і узагальнення, оскільки вони посідають важливе місце в структурі різних способів формування понять. Ці способи студенти реалізують на уроках біології під час педагогічної практики; вони залежать від категорії поняття, його структури, обсягу, змісту, а також від рівня сформованості в учнів теоретичних знань і значущості поняття в предметній підготовці.

Висновки. Будучи не новою, все ж проблема формування біологічних термінів та понять потребує особливої уваги з точки зору посилення практичної спрямованості підготовки майбутніх учителів біології в означеній галузі. В умовах реалізації компетентісно-орієнтованого підходу до навчання ДВНЗ «ПереяславХмельницький державний педагогічний університет імені Григорія Сковороди» у теоретичній і практичній підготовці майбутніх вчителів біології творчо застосовує 
Pedagogy

його концептуальні положення 3 метою подальшого його впровадження в практику навчання і виховання учнів загальноосвітньої школи.

\section{ЛІТЕРАТУРА}

Барна, 2006 - Барна Л. С. Підготовка вчителів біології: компетентнісний підхід / Л. С. Барна, М. М. Барна, А. В. Степанюк // Професійні компетенції та компетентності вчителя : матеріали регіонального науковопрактичного семінару. - Тернопіль : Вид-во ТНПУ ім. В. Гнатюка, 2006. - С. 147-152.

Грицай, 2012 - Грицай Н. Б. Формування методичної компетентності майбутніх учителів біології в умовах вищого навчального закладу / Н. Б. Грицай // Нова педагогічна думка : науково-методичний журнал. - Рівне, 2012. - № 1. - Ч. II. - С. 199-202.

Жорнова, 2013 - Жорнова О. І. Методична компетентність викладача ВНЗ / Ольга Жорнова, Олена Жорнова. - Навчальний посібник. Інтерсервіс, 2013. - 336 с.

Лейчик, 2009 - Лейчик В. М. Терминоведение: предмет, методы, структура М.: Либроком, 2009. - 256 с.

Колективна монографія, 2004 - Компетентнісний підхід у сучасній освіті: світовий досвід та українські перспективи. Колективна монографія / Під заг. ред. О. В. Овчарук. - К.: «К.І.С.» 2004. - 112 с.

Кузьмінський, 2012 - Кузьмінський А. І. Підготовка майбутнього фахівця у контексті компетентнісного підходу / А. І. Кузьмінський // Інформаційно-комунікаційні технології в сучасній освіті: досвід, проблеми, перспективи : зб. матер. III Міжнародної наук.-практ. конф. - Вип. 3. Частина 1. - КиївЛьвів, 2012. - С. 62-65.

Цуруль, 2004 - Цуруль О. А. Формування в учнів біологічних понять: психолого-педагогічні засади та методичні особливості : навчально-методичний посібник / О. А. Цуруль. - К. : НПУ імені М. П. Драгоманова, 2004. - 247 с.

\section{REFERENCES}

Barna, 2006 - Barna L. S. Pidhotovka vchyteliv biolohii: kompetentnisnyi pidkhid / L. S. Barna, M. M. Barna, A. V. Stepaniuk // Profesiini kompetentsii ta kompetentnosti vchytelia : materialy rehionalnoho naukovopraktychnoho seminaru. - Ternopil : Vyd-vo TNPU im. V. Hnatiuka, 2006. - S. 147-152.

Hrytsai, 2012 - Hrytsai N. B. Formuvannia metodychnoi kompetentnosti maibutnikh uchyteliv biolohii v umovakh vyshchoho navchalnoho zakladu / N. B. Hrytsai // Nova pedahohichna dumka : naukovo-metodychnyi zhurnal. - Rivne, 2012. - № 1. - Ch. II. - S. 199-202.

Zhornova, 2013 - Zhornova O. I., Zhornova O. I. Metodychna kompetentnist vykladacha VNZ / Olha Zhornova, Olena Zhornova. - Navchalnyi posibnyk Interservis, 2013. - $336 \mathrm{~s}$

Leychyk, 2009 - Leychyk V.M. Termynovedenye: predmet, metody, struktura M.: Lybrokom, 2009. - $256 \mathrm{~s}$.

Kolektyvna monohrafiia, 2004 - Kompetentnisnyi pidkhid u suchasnii osviti: svitovyi dosvid ta ukrainski perspektyvy. Kolektyvna monohrafiia / Kolektyv avtoriv: N. M. Bibik, L. M. Vashchenko, O. I. Lokshyna, O. V. Ovcharuk, 2004. - Ovcharuk, L. I. Parashchenko, O. I. Pometun, O. Ya. Savchenko / Pid zah. red. O. V. Ovcharuk. - K.: «K.I.S.» 2004. - 112 s.

Kuzminskyi, 2012 - Kuzminskyi A. I. Pidhotovka maibutnoho fakhivtsia u konteksti kompetentnisnoho pidkhodu / A. I. Kuzminskyi // Informatsiino-komunikatsiini tekhnolohii v suchasnii osviti: dosvid, problemy, perspektyvy : zb. mater. III Mizhnarodnoi nauk.-prakt. konf. - Vyp. 3. Chastyna 1. - Kyiv-Lviv, 2012. S. 62-65.

Tsurul, 2004 - Tsurul O. A. Formuvannia v uchniv biolohichnykh poniat: psykholoho-pedahohichni zasady ta metodychni osoblyvosti : navchalno-metodychnyi posibnyk / O. A. Tsurul. - K. : NPU imeni M. P. Drahomanova, 2004. - 247 s. 